\title{
Macroscopic and microscopic features of ulcerative stomatitis in farmed Atlantic salmon Salmo salar
}

\author{
P. F. Frelier ${ }^{1}$, R. A. Elston ${ }^{2}$, J. K. Loy ${ }^{1}$, C. Mincher ${ }^{1}$ \\ ${ }^{1}$ Department of Veterinary Pathobiology, College of Veterinary Medicine, Texas A\&M University, College Station, \\ Texas 77843, USA \\ ${ }^{2}$ Battelle Marine Research Laboratory, 439 West Sequim Bay Rd, Sequim, Washington 98382, USA
}

\begin{abstract}
Ulcerative stomatitis is an economically important disease of salmon smolts in net-pen farms of Puget Sound, Washington, USA. Gross lesions and losses from this disease typically occur 3 to 8 wk following introduction to sea water and may result in a cumulative mortality of up to $30 \%$ in some pens. The disease occurs seasonally and has been present on one farm since it began production in 1987 Ulcerated lesions are limited to the oral cavity, vary in size, and are associated with areas of dentition. Mats of Cytophaga-like filamentous bacteria are associated with areas of ulceration and necrosis and of ten extend into the underlying bone. Scanning electron microscopy demonstrated mats of filamentous bacteria overlying ulcerated areas and biofilms of filamentous bacteria adhering to tooth surfaces at the gingival-enameloid interface and invading the gingival epithelium. Our findings suggest the filamentous bacterium plays a major role in the pathogenesis of ulcerative stomatitis in salmon smolts.
\end{abstract}

KEY WORDS: Atlantic salmon - Salmo salar - Bacterial disease Stomatitis C Cytophaga-like - Flexibacter-like

Filamentous, nonphotosynthetic, nonfruiting, Gramnegative bacteria that are pathogenic to fish and are able to demonstrate a slow, gliding type of motility are included in the order Cytophagales (Larkin 1989). Although many species of bacteria within this order are pathogenic to freshwater fish (Frerichs \& Roberts 1989), only a few pathogenic species have been identified from the marine environment (Sawyer 1976, Masumura \& Wakabayashi 1977, Wakabayashi et al. 1984, Kent et al. 1988, Dungan et al. 1989, Bernardet et al. 1990).

Mortality of Atlantic salmon Salmo salar smolts up to 6 mo after introduction to sea water has been attributed to various causes including inadequate smoltification, poor feeding, and several infectious diseases. A disease survey of net-pen reared salmon from Puget
Sound, Washington, USA, during 1990 and 1991 revealed an association of dead and moribund smolts with a subacute, multifocal, ulcerative stomatitis. The disease occurred on 4 farms representing 5 sites with a combined annual production of over 1500 tons and was considered by farm managers to be the most severe infectious disease in 1990 and 1991. Reports from fish farmers in British Columbia indicated the loss of approximately 139000 smolts in 1989 associated with an apparently identical disease $(M$. Shephard pers. comm). Initial lesions of the disease proved to have a uniform character and were associated with a filamentous Cytophaga-like bacterium. The purpose of this report is to provide a detailed morphologic description of the disease and to discuss the findings in relation to pathogenesis of the disease. Additional studies regarding biochemical and molecular characterization of the associated organism are under way and will be reported in a subsequent paper.

Material and methods. Affected smolts recently introduced to sea water were obtained from 4 net-pen farms in Puget Sound, Washington, USA, from April to July 1990 and 1991. Affected smolts were obtained from pens where oral lesions had been directly associated with mortalities. The 7 to 12 mo old smolts were directly introduced to sea water net-pens at a density of approximately $25 \mathrm{~kg} \mathrm{~m}^{-3}$ and weighed between 50 and $80 \mathrm{~g}$ when stocked.

Tissues were selected for necropsy from 8 dead, moribund, or clinically ill Atlantic salmon demonstrating characteristic oral lesions. Fish from 3 farms were examined in detail. Tissues were fixed in Davidson's solution (Humason 1979), processed, and stained with hematoxylin and eosin for morphologic examination. Selected tissues were stained with a BrownHopp's modified Gram stain (Sheehan \& Hrapchak 
Table 1 Results of necropsy survey for necrotizing stomatitis from 3 netpen salmon farms in Puget Sound, Washington, USA.

\begin{tabular}{|ccccc}
\hline \multicolumn{2}{c}{ Species } & \multicolumn{2}{c}{1990} & \multicolumn{2}{c}{1991} \\
& No. examined & $\%$ affected & No. examined & $\%$ affected \\
\hline AS & 626 & 13.4 & 670 & 9 \\
CS & 227 & 0 & 14 & 0 \\
RT & 260 & 11.5 & 26 & 9.5
\end{tabular}

AS = Atlantic salmon Salmo salar, $\mathrm{CS}=$ chinook salmon Oncorhynchus tshawytscha; RT = rainbow trout Oncorhynchus mykiss containing an overlying layer of yellow to tan friable material. Lesions were characteristically associated with regions of dentition including the premaxilla, dentary, vomer, and palatine bones. Tooth loss was often present in the affected areas. In many cases the opposing surfaces of the dentary and premaxilla bones were affected. Gramstained smears of the ulcerated areas demonstrated large numbers of uniform, Gram-negative 2.5 to $13 \mu \mathrm{m}$ long filamentous organisms.

1980). Tissues of the oral cavity and tissues from the heart, gills, liver, spleen, anterior and posterior kidney, and brain were also examined.

Oral tissues from 3 of the smolts containing the typical lesions and 2 macroscopically normal smolts were examined by scanning electron microscopy (SEM) These tissues were fixed in $4 \%$ glutaraldehyde in $0.1 \mathrm{M}$ sodium cacodylate adjusted to $\mathrm{pH} 7.2$ and then rinsed in $0.1 \mathrm{M}$ cacodylate. Tissues were postfixed in $1 \%$ osmium tetroxide containing sodium cacodylate buffer, dehydrated in acetone, critical point dried with carbon dioxide, sputter coated with gold, and examined on a JEOL JSM.25S scanning electron microscope.

Impression smears of oral lesions were stained with Giemsa and Gram stains and examined microscopically.

Lesions from selected smolts were dissected, minced in sterile $50 \%$ sea water, and dilution-plated onto both cytophaga medium (Difco) made with $50 \%$ sea water and marine agar (Difco) (Anacker \& Ordal 1959).

Results. Disease outbreaks occurred from April to July when water temperatures were between 8 and $12^{\circ} \mathrm{C}$ and salinity was between 29 and $32 \%$ Mortality and morbidity were observed in smolts 3 to $8 \mathrm{wk}$ following sea water introduction. Cumulative pen mortalities of smolts with characteristic oral lesions during the first $6 \mathrm{wk}$ post introduction were typically between 5 and $10 \%$, but occasionally reached as high as $30 \%$.

From April to August in 1990 and 1991, 10\% and $9 \%$, respectively, of the 1113 and 710 fish necropsied demonstrated lesions of ulcerative stomatitis. In 1990 , $13 \%$ of the Atlantic salmon, and $12 \%$ of rainbow trout Oncorhynchus mykiss examined were affected. In $1991,9 \%$ of the Atlantic salmon, and $10 \%$ of rainbow trout examined were affected. The disease was not identified in any of the 241 chinook salmon Oncorhynchus tshawytscha examined (Table 1).

Macroscopic findings and bacteriology: Macroscopic lesions occurred in various parts of the oral cavity and consisted of an acute necrotizing ulcerative gingivitis, glossitis and/or stomatitis. These lesions were 1 to $5 \mathrm{~mm}$, round to spherical uicerated areas
Successful culture of the presumptive causative agent of this disease required careful dissection and washing of the lesions and serial-dilution plating due to the expected surface contaminants of the lesions. Once this method was refined, pure cultures of a single colony type were obtained. Cells in the colonies were thin, Gram-negative rods typical of a Cytophaga sp.

Microscopic findings: Oral tissues from 1 smolt demonstrated what we interpreted as the initial lesion, which was characterized by spongiosis of the epithelial layer due to interepithelial edema with separation of individual epithelial cells and transepithelial inflammatory cell migration. The epithelium was intact but contained an overlying mat of filamentous bacteria. Patchy areas in the stratum spongiosum contained neutrophils and mononuclear cells. A single lymphatic contained an organized thrombus.

In the remaining smolts the predominant oral lesion consisted of a focal ulcerated area that extended to the stratum spongiosum or stratum compactum. The ulcer frequently had an overlying layer of dense bacteria mixed with necrotic debris (Fig. 1). With the Gram stain, dense masses of filamentous, Gram-negative bacterial rods in the overlying debris and variable numbers of similar rods invading the underlying stroma were evident. An inflammatory reaction consisting of mononuclear cells and polymorphonuclear cells surrounded the underlying edematous areas, occasionally extending to the underlying bone and laterally beyond the edge of the ulcer In one case, the filamentous bacteria formed a compact linear zone aligned perpendicular to the axis of the bone. With the Gram stain, it was evident that the bacteria had penetrated the superficial layer of bone but that there was little inflammatory cell infiltration of the bone.

In some smolts, osteonecrosis of the jawbone underlying the ulcerated foci was present and characterized by loss of osteocytes and osteoblasts. Osteoclasts were often adjacent to necrotic bone with irregular scalloping of the bone surface.

No lesions were present in the other organs examined. 


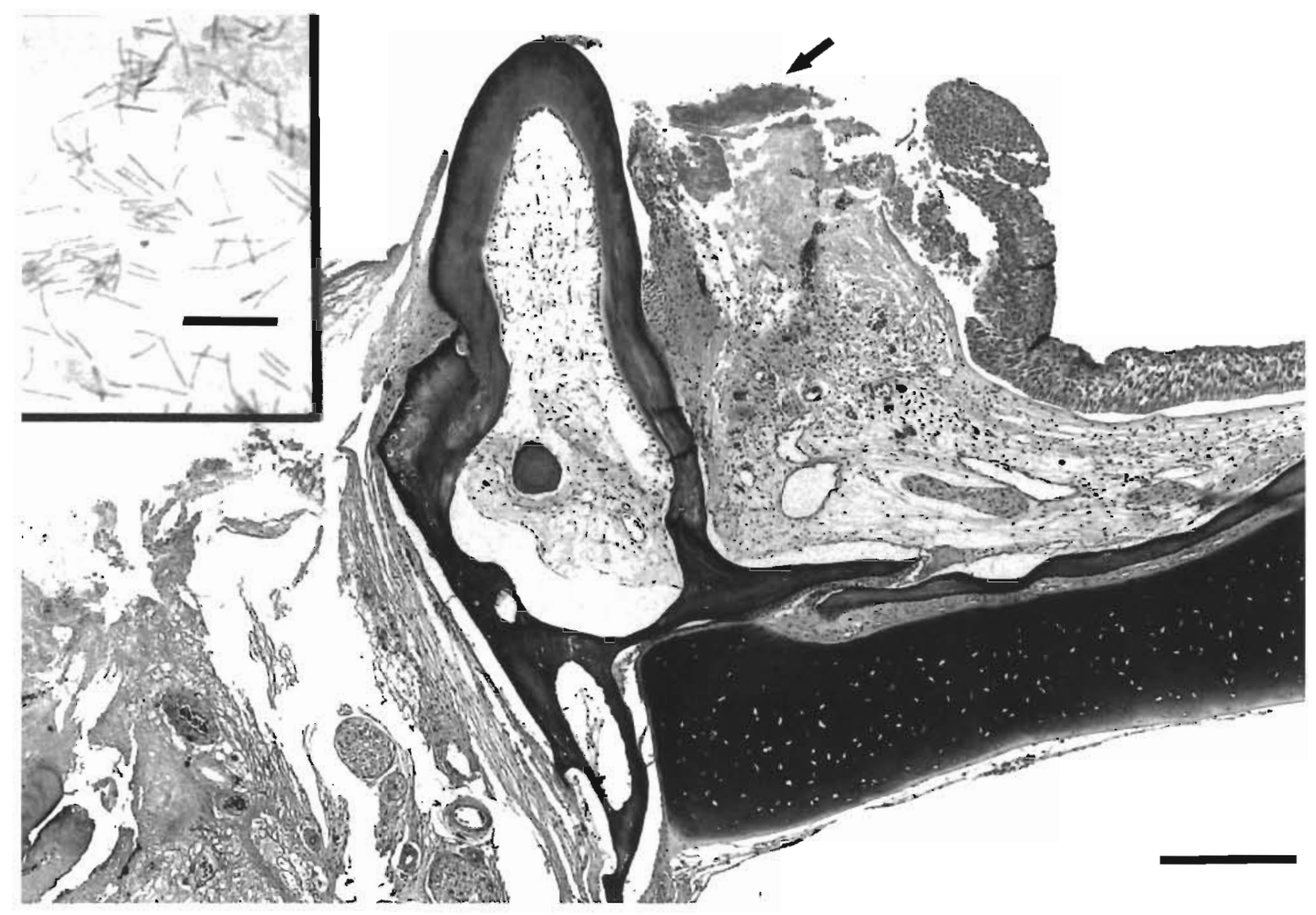

Fig. 1. Salmo salar. Necrosis and ulceration of the periodontium and gingiva. Note the mass of bacteria (arrow) overlying the ulcer and invading adjacent subgingival tissues. H\&E. Scale bar $=250 \mu \mathrm{m}$. Inset: impression smear of ulcer with characteristic filamentous bacteria. Gram stain. Scale bar $=10 \mu \mathrm{m}$

UItrastructural findings: SEM of ulcerated areas affected fish demonstrated exposure of proximal tooth roots and periodontal cavities. Aggregates or mats of filamentous, bacterial rods were often present in the cellular debris at the gingival-enameloid interface and formed subgingival and coronal plaques (Fig. 2). Variable numbers of individual bacterial rods often covered the proximal tooth surface forming a single cell thick, confluent biofilm. Many of these bacteria contained multiple, elongated lateral fibrillar appendages anchoring the attached bacteria to the underlying tooth. Shallow pits of the tooth surface were often associated with these surface-adhering bacteria. Superficial aggregates of bacterial rods, distant from the ulcerated regions, were present overlying the intact epithelium. Interepithelial bacterial invasion was associated with bacterial aggregates.

Discussion. Examination of moribund or dead smolts with oral ulcers indicated mortalities were associated with large numbers of superficial and intralesional filamentous, thin, Gram-negative bacterial rods measu- ring 2.5 to $13.0 \mu \mathrm{m}$ in length. Morphologically similar oral lesions containing bacteria similar to those described in this report have been documented in marine cultured fish. Mass mortalities in red sea bream Pagrus major and black sea bream Acanthopagrus schlegeli cultured in sea cages in Japan were associated with oral and caudal fin erosions. The ulcerated lesions were pale yellow due to large numbers of filamentous, thin, 0.3 to $0.5 \mu \mathrm{m} \times 2$ to $6 \mu \mathrm{m}$ bacterial rods overlying the lesion surface. The name Flexibacter maritimus has been proposed for this bacterium (Wakabayashi et al. 1986). Severe mortality occurred in coho salmon Oncorhynchus kisutch smolts introduced to seawater net-pens in Maine (Sawyer 1976). Affected fish had severe erosion of the nose, mouth, and lower jaw. Yellow mats of gliding bacteria were observed in the mouth, pharynx, and pneumatic duct. The outbreak was originally referred to as a myxobacterial disease although biochemically the organism was similar to Flexibacter (Sawyer 1976). This organism was morphologically and physiologically similar to Flexibacter maritimus 


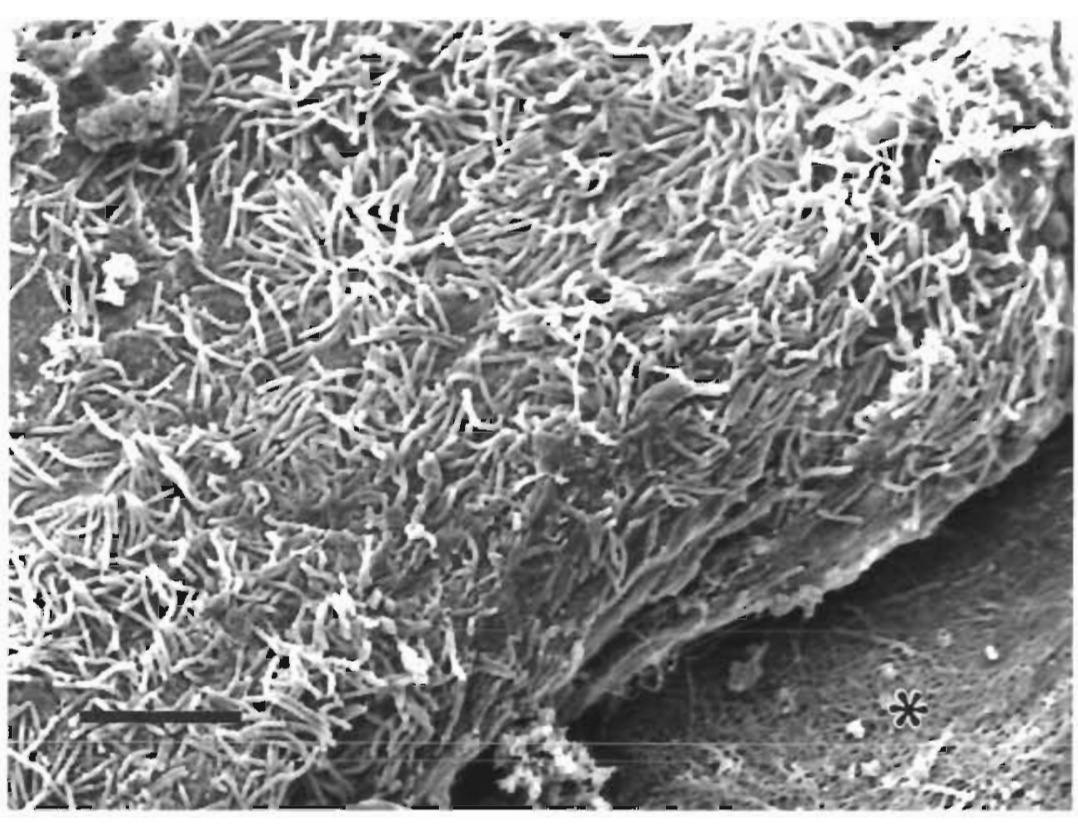

Fig. 2. Salmo salar. Dense mat of filamentous bacteria associated with peridontal lesion. Adjacent tooth is undergoing dissolution (asterisk). Scale bar $=10 \mu \mathrm{m}$.

termined but is attributed to osmoregulatory abnormalities following epithelial damage and ulceration. Edema of the strata spongiosum and compactum was consistently present underlying and surrounding the ulcers. Abnormal elevated plasma sodium levels have been demonstrated in moribund smolts with focal ulcerations with adjacent edema of the body wall (Kent et al. 1988). Although bacterial invasion often extended to the stratum compactum and underlying bone, no evidence of endotoxemia including petechiae, focai necrosis of spleen, kidney, liver, and hematopoietic elements was observed in any of the fish examined (Roberts 1989). Bacteria were also not demonstrable in any of the additional organs examined including the posterior kidney, indicating the absence of a bacteremia.

We were unable to elucidate the

except that it grew in $\mathrm{NaCl}$ as well as in sea-water containing media. F maritimus has an obligate requirement for sea water (Wakabayashi et al. 1986).

Morphologic similarities of the organism and of the lesions described in this study with previous published cases of oral ulceration in finfish suggest the organism in Atlantic salmon is a Cytophaga-like bacterium (Roberts \& Shepherd 1986, Masumura \& Wakabayashi 1977). Two genera, Cytophaga and Flexibacter, belong to the order Cytophagales. Distinction between these 2 taxa is currently not clear (Bernardet \& Grimont 1989). Three species within the order Cytophagales, 'Cytophaga (Flexibacter) columnaris', 'Cytophaga psychrophila', and Flexibacter maritimus, are pathogenic to fish. The former 2 occur in fresh water. Names of species not validated in the International Journal of Systemic Bacteriology are cited in quotation marks

During 1990 and 1991, the average proportion of mortality attributable to ulcerative stomatitis was $10 \%$, considering all locations. However, the attributed mortality rate ranged from 1 to $20 \%$ on given sample dates and depending on the location. The actual percentage of deaths resulting from this disease may have been substantially higher based on observations made by fish-farm workers. However, without precise information on the rate of disease progression, a more accurate level of mortality cannot be assigned. Although species other than Atlantic salmon were affected, the data on these species are insufficient to permit an estimate of the relative susceptibility by species.

The cause of death in the present cases was not de- factors responsible for initial bacterial colonization and for promotion of subsequent bacterial proliferation. The Cytophaga sp. that infects seawater smolts and results in skin and muscle necrosis may represent a different bacterial species, as infection of the oral cavity was not reported in any of these cases (Kent et al. 1988). Although diseases caused by Flexibacter and Cytophaga spp. are usually secondary to perturbations of the normal mucus or epithelial cell protective barrier, we were unable to consistently identify early uninfected oral lesions, either before or during a disease outbreak. Attachment of Caprella sp. to the oral cavity of smolts was sometimes noted but was not a consistent finding preceding or during the development of the ulcerative stomatitis in smolts. We were also not able to attribute disease outbreaks to any specific farm management practices which included size of the pellet fed or the size or shape of the mesh opening used for the net-pen.

Oral lesions were characteristically associated with areas of dentition. Ultrastucturally, bacteria formed a single cell thick uniform biofilm on the tooth enameloid. Adherence of the bacteria to the tooth surface may be an important initiating factor in the pathogenesis of this disease. Additionally, bacteria in the shallow pits of the enameloid suggest preferential bacterial localization and colonization with the production of bacterial extracellular enzymes leading to subsequent enameloid erosion (Savage \& Fletcher 1985). It has been demonstrated that calcium promotes growth of different pathogenic strains of Flexibacter spp. when 
added to the culture medium (Hikida et al. 1979). The enameloid of teleost teeth is highly mineralized and could serve as a source of calcium to the bacteria (Shellis \& Miles 1974). The mechanism of attachment to the enameloid surface may be similar to that of other bacteria associated with dental plaques and involve direct adsorption to enamel hydroxyapatite (Savage \& Fletcher 1985). Once established on the tooth surface in a favorable microenvironment, these filamentous bacteria could proliferate and invade the adjacent subgingiva and gingiva as occurs in man (Listgarten et al. 1975).

Our findings suggest the filamentous bacterium plays a major role in the pathogenesis of the disease and that the pathogenesis of ulcerative stomatitis in salmonid smolts may be similar to gingival diseases in man. Additional biochemical and molecular studies are in progress to identify the filamentous bacterium.

Acknowledgements. This work was supported by a Saltonstall-Kennedy grant NA26FDO448 from the National Marine Fisheries Service, U.S. Department of Commerce.

\section{LITERATURE CITED}

Bernardet, J. F., Campbell, A. C., Buswell, J. A. (1990). Flexibacter maritimus is the agent of 'black patch necrosis' in Dover sole in Scotland. Dis, aquat. Org. 8 : $233-237$

Bernardet, J. F., Grimont, P. (1989). Deoxyribonucleic acid relatedness phenotypic characterization of Flexibacter columnaris sp. nov., nom. rev., Flexibacter psychrophilus sp. nov., nom. rev., and Flexibacter maritimus. Int. J. Syst. Bacteriol. 39: 346-354

Dungan, C. F., Elston, R. A., Schiewe, M. H. (1989). Evidence for colonization and destruction of hinge ligaments in cultured juvenile Pacific oysters (Crassostrea gigas) by

Responsible Subject Editor: T. Evelyn, Nanaimo, B.C. Canada
Cytophaga-like bacteria. Appl. environ. Microbiol. 55: $1128-1135$

Hikida, M., Wakabayashi, H., Egusa, S., Masumura, K. (1979). Flexibacter sp., a gliding bacterium pathogenic to some marine fishes in Japan. Bull. Jap. Soc. scient. Fish. 45: $421-428$

Humason, G. L. (1979). Animal tissue techniques. W. H. Freeman, San Francisco

Kent, M. L., Dungan, C. F., Elston, R. A., Holt, R. A. (1988). Cytophaga sp. (Cytophagales) infection in seawater penreared Atlantic salmon Salmo salar. Dis. aquat. Org. 4 : $173-179$

Larkin, J. M. (1989). Order Cytophagales. In: Staley, J. T., Bryant, M. P., Fennig, N. (eds.) Bergey's manual of systematic bacteriology, Vol. 3. Williams \& Wilkins, Baltimore, p. $2010-2050$

Listgarten, M. A., Mayo, H. E., Tremblay, R. (1975). Development of dental plaque on epoxy resin crowns in man. J. Periodontol. 46: 10-26

Masumura, K., Wakabayashi, H. (1977). An outbreak of gliding bacterial disease in hatchery-born red sea bream (Pagrus major) and gilthead (Acanthopagrus schlegeli) fry in Hiroshima. Fish Pathol. 12: 171-177

Roberts, R. J., Shepherd, C. J. (1986). Handbook of trout and salmon diseases. Fishing News Books Ltd, Surrey

Savage, D. S., Fletcher, M. (1985). Bacterial adhesion: mechanisms and physiological significance. Plenum Press, New York

Sawyer, E. S. (1976). An outbreak of myxobacterial disease in coho salmon (Oncorhynchus kisutch) reared in a Maine estuary. J. Wildl. Dis. 12: 575-578

Sheehan, D. C., Hrapchak, B. B. (1980). Theory and practice of histotechnology. C. V. Mosby Co., St. Louis

Shellis, R. P., Miles, A. E. (1974). Autoradiographic study of the formation of enameloid and dentine matrices in teleost fishes using tritiated amino acids. Proc. R. Soc. Lond. B 185: $51-72$

Wakabayashi, H., Hikida, M., Masumura, K. (1984). Flexibacter infection in cultured marine fish in Japan. Helgoländer Meeresunters. 37: 587-593

Wakabayashi, H., Hikida, M., Masumura, K. (1986). Flexibacter maritimus $\mathrm{sp}$. nov., a pathogen of marine fishes. Int. J. Syst. Bacteriol. 36: 396-398

Manuscript first received: December 4, 1992 Revised version accepted: November 2, 1993 